\title{
Elementary Student Perspectives on Single-Gender Classes
}

\author{
Mercedes Tichenor ${ }^{1, *}$, John Tichenor ${ }^{2}$, Kathy Piechura ${ }^{1}$, Elizabeth Heins ${ }^{1} \&$ Doug MacIssac ${ }^{1}$ \\ ${ }^{1}$ Department of Education, Stetson University, DeLand, Florida, USA \\ ${ }^{2}$ School of Business, Stetson University, DeLand, Florida, USA \\ *Correspondence: Department of Education, 421 N. Woodland Blvd. Unit 8419, Stetson University, DeLand, FL \\ 32723, USA. Tel: 1-386-822-7086. E-mail: mticheno@stetson.edu
}

Received: June 18, 2015 Accepted: August 22, 2015 Online Published: October 2, 2015

doi:10.5430/jct.v4n2p80 URL: http://dx.doi.org/10.5430/jct.v4n2p80

\begin{abstract}
Interest in single-gender education has grown significantly since the U.S. Department of Education published regulations for the practice in 2006. Although research provides mixed results on the academic effectiveness of single-gender programs, many districts around the country are providing single-gender classes as a parent choice option under the NCLB Act. The option for single-gender classes in public education highlights the importance of examining student perspectives toward this configuration. This study examines the views of 131 elementary school students regarding single-gender education in an elementary school that has offered single-gender classes for 10 years. Overall, the results suggest that students have positive attitudes toward their single-gender classrooms. Most students believe that the single-gender classroom format positively impacted them in many important school dimensions such as self-confidence, motivation, self-esteem, independence, self-efficacy, attitude, and grades.
\end{abstract}

Keywords: single-gender, attitudes, elementary students

\section{Introduction}

Interest in single-gender education has grown significantly since the U.S. Department of Education published regulations for the practice in 2006 (Protheroe, 2009). These regulations, required by section 5131(c) of the No Child Left Behind legislation, allow coeducational public schools to offer single-gender classrooms provided that the schools: 1) state a rationale for single-gender classes, 2) provide coeducational classes in the same geographic area, and 3) conduct a review every two years to determine if the single-gender classrooms are viable. The pedagogical rationale for this educational strategy is based on the belief that boys and girls learn differently and might benefit from instruction divided by gender. While still uncommon in the overall landscape of public education, single-gender education in public school settings has grown substantially (Bigler \& Signorella, 2011). Many districts around the country are providing single-gender classes as a parent choice option under the NCLB Act. According to the National Association for Single-Sex Public Education (NASSPE), approximately 515 public schools in the United States offered single-gender experiences in the 2011-2012 academic year. In May 2014, Florida governor Rick Scott signed legislation (HB 313) allowing each school district in the state to offer a single-gender option.

Given the significant growth over the past ten years, there is still limited research in this area and the available studies provide mixed results on the academic effectiveness of single-gender classes (Bracey, 2006; Solomone, 2013; Spielhagen, 2013; U.S. Department of Education, 2014). Thus, more research is needed to understand the impact of single-gender education. In this exploratory study, we examine the perspectives of 131 elementary school students who were enrolled in single-gender classrooms during the 2013-2014 school year. We examine their perspectives about many aspects of single-gender education to address three basic questions:

1) Are students satisfied with a single-gender format?

2) What aspects of single-gender classrooms do students like best?

3) Do students in single-gender classes want to continue in single-gender classrooms?

In a recent study, parents of elementary school students in single-gender classrooms responded very favorably and believed that the single-gender format positively impacted their child's self-confidence, motivation, independence, 
self-efficacy, attitude, and grades (Tichenor, Tichenor, Piechura, \& Heins, 2012). In a study of middle school students, Spielhagen (2006) found that $6^{\text {th }}, 7^{\text {th }}$, and $8^{\text {th }}$ grade students believe that single-gender classes can be an effective alternative in middle schools if developmentally appropriate. In his in-depth interviews with twenty-four middle-schoolers, he also found that younger middle school students were more likely to find single-gender classes a positive experience than older students in middle school (Spielhagen, 2006).

\section{Method}

This study examines the views of elementary school students regarding single-gender education in a public elementary school that has offered single-gender classes along with mixed-gender classes since 2004 . The elementary school has approximately 640 students in grades preK-5. Of the total school population, approximately $62 \%$ are White, $18 \%$ are Black, $15 \%$ are Hispanic, $4 \%$ are Multiracial and $1 \%$ is Asian. Approximately seventy-five percent of these students are eligible for free or reduced lunch. Students are assigned to single-gender classes as they are to mixed-gender classes (the administration makes a great effort to balance classes with an equal mix of high performing and low performing students as well as students of varying races and ethnicities in both single and mixed-gender classes). The only difference between the mixed-gender and single-gender classes is that parents in the single-gender program have the right to "opt in" to a single-gender classroom. In other words, parents must give permission for their children to be placed in a single-gender classroom.

At the time of the study, there were single-gender classrooms in kindergarten, first, second, third, and fourth grades (there were no fifth-grade single-gender classrooms because the number of girls and boys did not allow the possibility of offering balanced mixed-gender classes). However, kindergarten students were not included in the study because they have limited schooling experience and little context for comparing their experiences in single-gender settings. In grades 1 through 4, there were 141 students participating in single-gender classes. A total of 131 students completed the survey ( $93 \%$ of the single-gender students). Students who were absent when the survey was completed did not participate in this study.

The survey instrument used in the study was developed by South Carolina Department of Education's Office of Public School Choice. The general categories addressed in the survey include self-confidence, motivation, independence, attitude about school, grades, and behavior. Students in single-gender classrooms were asked to respond to 19 items regarding their attitudes about being in single-gender classes. Each of the survey items was asked with the following, student-friendly instructions:

On the number lines below each item, circle one number that best describes how you feel about the different aspects of your classroom with all boys/girls.

\begin{tabular}{|c|c|c|c|c|c|c|}
\hline : & & \multicolumn{3}{|c|}{ :- } & \multicolumn{2}{|r|}{;) } \\
\hline 1 & 2 & 3 & 4 & 5 & 6 & 7 \\
\hline A L & \multicolumn{4}{|c|}{ About the same } & \multicolumn{2}{|r|}{ A Lot More } \\
\hline
\end{tabular}

The surveys were distributed in each classroom by a university researcher at the end of the academic school year. While the researchers were careful to present each item in a natural, non-biased manner, they also helped students by clarifying the meaning of the survey items and by providing appropriate examples. The students completed the survey in approximately 30 minutes as the researchers read each item to them. Students were encouraged to answer openly and were asked not to write their names on the survey. To encourage open and honest responses, the students were told that there were no correct or incorrect answers to the questions.

As illustrated in Table 1., the distribution of student respondents in single-gender classrooms by grade level ranged from 27 students in third grade to 36 in first grade. The single-gender program at this school is designed to have approximately equal-sized classes of boys and girls. Of the total students surveyed in single-gender classes, 66 (50.3 percent) are boys and 65 (49.6 percent) are girls. 
Table 1. Student Respondents by Grade Level and Gender

\begin{tabular}{llll}
\hline Grade Level & Boys & Girls & Total \\
\hline First & 19 & 17 & 36 \\
Second & 17 & 16 & 33 \\
Third & 14 & 13 & 27 \\
Fourth & 16 & 19 & 35 \\
Total & $\mathbf{6 6}$ & $\mathbf{6 5}$ & $\mathbf{1 3 1}$ \\
\hline
\end{tabular}

\section{Results}

Table 2. Student Results by Gender (All Grade Levels)

\begin{tabular}{|c|c|c|c|c|}
\hline Survey Item & $\begin{array}{l}\text { Boys } \\
\text { mean }\end{array}$ & $\begin{array}{c}\text { Boys } \\
\text { std. } \\
\text { dev. }\end{array}$ & $\begin{array}{l}\text { Girls } \\
\text { mean }\end{array}$ & $\begin{array}{c}\text { Girls } \\
\text { std. } \\
\text { dev. }\end{array}$ \\
\hline 1. Do you enjoy being in school less or more in your all-boy/girl classes? & 6.39 & 1.08 & 6.11 & 1.29 \\
\hline 2. Do you follow the class rules less or more when in your all-boy/girl classes?* & 5.56 & 1.72 & 6.17 & 1.21 \\
\hline 3. Are you less or more proud of yourself when in the all-boy/girl classes? & 6.26 & 1.24 & 6.34 & 1.34 \\
\hline $\begin{array}{l}\text { 4. Do you want to do your work less or more when being in your all-boy/girl } \\
\text { classes? }\end{array}$ & 5.62 & 1.88 & 5.75 & 2.00 \\
\hline $\begin{array}{l}\text { 5. Do you like to try new activities less or more when being in your all-boy/girl } \\
\text { classes? }\end{array}$ & 6.38 & 1.26 & 6.69 & 0.93 \\
\hline $\begin{array}{l}\text { 6. Are you less or more comfortable to work on your own when in your all-boy/girl } \\
\text { classes? }\end{array}$ & 5.03 & 2.07 & 5.61 & 2.12 \\
\hline $\begin{array}{l}\text { 7. Do you ask questions and share ideas less or more when in your all-boy/girl } \\
\text { classes?* }\end{array}$ & 5.61 & 1.97 & 6.29 & 1.30 \\
\hline $\begin{array}{l}\text { 8. Do you think you are less or more able to be successful when doing the work in } \\
\text { your all-boy/girl classes? }\end{array}$ & 6.12 & 1.45 & 6.33 & 1.26 \\
\hline 9. Are you learning less or more when in your all-boy/girl classes? & 6.24 & 1.31 & 6.60 & 1.01 \\
\hline 10. Do you want to finish hard work less or more when in your all-boy/girl classes? & 5.47 & 2.07 & 5.53 & 1.99 \\
\hline 11. Are you less or more able to make friends when in your all-boy/girl classes? & 6.50 & 1.38 & 6.23 & 1.48 \\
\hline $\begin{array}{l}\text { 12. Do you think that being in school is better or worse when in your all-boy/girl } \\
\text { classes? }\end{array}$ & 6.00 & 1.72 & 6.05 & 1.44 \\
\hline $\begin{array}{l}\text { 13. Do you complete less or more of the class work in your all-boy/girl classes than } \\
\text { you usually do? }\end{array}$ & 5.77 & 1.68 & 5.91 & 1.66 \\
\hline $\begin{array}{l}\text { 14. Do you complete less or more of the homework for your all-boy/girl classes } \\
\text { than you usually do? }\end{array}$ & 5.98 & 1.64 & 5.92 & 1.56 \\
\hline $\begin{array}{l}\text { 15. Are you less or more able to pay attention during class when in your } \\
\text { all-boy/girl classes? }\end{array}$ & 5.94 & 1.65 & 5.98 & 1.61 \\
\hline 16. Are you less or more interested in reading when in your all-boy/girl class? & 5.82 & 1.86 & 6.05 & 1.53 \\
\hline 17. Are you less or more interested in mathematics when in your all-boy/girl class? & 5.88 & 2.00 & 6.06 & 1.68 \\
\hline 18. Are you less or more interested in science when in your all-boy/girl class? & 6.24 & 1.43 & 6.03 & 1.53 \\
\hline $\begin{array}{l}\text { 19. Are you less or more interested in social studies when in your all-boy/girl } \\
\text { class? }\end{array}$ & 5.53 & 2.06 & 5.72 & 1.72 \\
\hline
\end{tabular}

$* \mathrm{p}<=.05$ for mean difference between boys and girls

Students were asked to respond to a series of items regarding their views of the single-gender classroom. The response categories for each item ranged from 1 to 7 and addressed a variety of issues, from self-confidence to grades. Means and standard deviations for each item are presented in Table 2. Responses closer to 7 indicate more positive response to the single-gender program. Likewise, lower numbers indicate less positive response on the items. Overall, both boys and girls seem to be very positive about the single-gender program. For each of the 19 items, the mean response was greater than 5 on the 7-point scale. The item with the highest mean for boys is "Are you less or more able to make friends when in your all-boy/girl classes?" (mean=6.50 on 7-point scale) while the lowest mean for boys is "Are you less or more comfortable to work on your own when in your all-boy/girl classes?" (mean=5.03 on 7-point scale). For 
girls, the highest item is "Do you like to try new activities less or more when being in your all-boy/girl classes?" (mean=6.69) and the lowest mean is for the item, "Do you want to finish hard work less or more when in your all-boy/girl classes?" (mean=5.53). These results seem to indicate that students are very positive about their experiences in single-gender classes. Further, the existence of variation in the student responses indicates that the students were thoughtfully considering their responses (i.e., the students were not simply marking the highest responses due to some sort of social response bias).

The responses for boys and girls were similar on 17 of the 19 items. In other words, both boys and girls gave consistently high responses on the items. However, there were statistically significant differences between boys and girls on two items. Specifically, girls gave more positive responses than boys on items 2 and 7 . Girls reported following class rules (item 2) more than boys when they are in their all-girl classes (girls' mean $=6.17$, boys' mean $=5.56$ ). Girls also reported that they ask questions and share ideas more when they are in their all-girl classes (girls' mean $=6.29$, boys' mean $=5.61$ ). Using t-tests to compare the differences between means of independent samples, these two items ( 2 and 7 ) indicate that the difference between boys' and girls' responses are statistically significant at alpha $=.05$. In other words, the higher means for girls on these two items are not likely simply due to random sampling error.

While the overall results seem to indicate that both boys and girls are positive about single-gender classrooms, we also examined the results for differences by grade level and by gender within grade level. For 15 of the 19 items, there were no statistically significant differences by grade level. However, one-way analysis of variance (ANOVA) results indicate that there are grade-level differences on four of the 19 items. The ANOVA statistics for these four variables are presented in Table 3 .

Table 3. ANOVA Results for Items with Statistically Significant Differences by Grade Level

\begin{tabular}{llrrrrc}
\hline & & \multicolumn{1}{c}{ Sum of } \\
& & & & & \\
& Squares & Df & Mean Square & \multicolumn{1}{c}{ F } & Sig. \\
\hline Do you enjoy being in school & Between Groups & 16.238 & 3 & 5.413 & 4.081 & .008 \\
less or more in your all-boy/girl & Within Groups & 168.449 & 127 & 1.326 & & \\
classes? & Total & 184.687 & 130 & & & \\
Are you less or more proud of & Between Groups & 12.797 & 3 & 4.266 & 2.674 & .050 \\
yourself when in the all-boy & Within Groups & 202.592 & 127 & 1.595 & & \\
classes? & Total & 215.389 & 130 & & & \\
Are you less or more interested & Between Groups & 33.619 & 3 & 11.206 & 4.160 & .008 \\
in reading when in your & Within Groups & 336.754 & 125 & 2.694 & & \\
all-boy/girl class? & Total & 370.372 & 128 & & & \\
Are you less or more interested & Between Groups & 34.813 & 3 & 11.604 & 3.428 & .019 \\
in social studies when in your & Within Groups & 429.858 & 127 & 3.385 & & \\
all-boy/girl class? & Total & 464.672 & 130 & & & \\
\hline
\end{tabular}

Post-hoc analyses indicate that the statistically significant differences on the items are between grade levels one and four. Table 4. presents the descriptive statistics for first and fourth graders for these four items. These results are particularly interesting because they may support Spielhagen's (2006) finding that older students are less favorable toward single gender education than younger students.

Table 4. Student Results (Means Only) by Gender and Grade Level

\begin{tabular}{lcc}
\hline Survey Item & $\mathbf{1}^{\text {st }}$ Graders & $\mathbf{4}^{\text {nd }}$ Graders \\
\hline Do you enjoy being in school less or more & Mean $=6.75$ & Mean $=5.83$ \\
in your all-boy/girl classes? & s.d. $=.77$ & s.d. $=1.25$ \\
Are you less or more proud of yourself & Mean $=6.58$ & Mean $=5.80$ \\
when in the all-boy/girl classes? & s.d. $=1.05$ & s.d. $=1.61$ \\
Are you less or more interested in reading & Mean $=6.49$ & Mean $=5.14$ \\
when in your all-boy/girl class? & s.d. $=.77$ & s.d. $=1.77$ \\
Are you less or more interested in social & Mean $=6.08$ & Mean $=4.80$ \\
studies when in your all-boy/girl class? & s.d. $=1.87$ & s.d. $=1.89$ \\
\hline
\end{tabular}


Students were also asked to respond to the question, "Would you want to be in all boy/girl classroom next year?" The results for this item are presented in Table 5. Overall, approximately 81 percent of the students responded that they would like to be in a single-gender class next year, approximately 11 percent responded "maybe" and only 8 percent responded "no." The differences between boys and girls are not statistically significant. These results are further indication of the students' overall positive reaction to single-gender classrooms.

Table 5. Would You Want to Be in All Boy/Girl Classroom Next Year?

\begin{tabular}{cccc}
\hline & Boys & Girls & Total \\
\hline Yes & 54 & 52 & 106 \\
& $(81.8 \%)$ & $(80.0 \%)$ & $(80.9 \%)$ \\
Maybe & 5 & 9 & 14 \\
& $(7.6 \%)$ & $(13.8 \%)$ & $(10.7 \%)$ \\
No & 7 & 4 & 11 \\
& $(10.6 \%)$ & $(6.2 \%)$ & $(8.4 \%)$ \\
Total & $\mathbf{6 6}$ & $\mathbf{6 5}$ & $\mathbf{1 3 1}$ \\
& $(\mathbf{1 0 0 . 0 \% )}$ & $(\mathbf{1 0 0 . 0 \% )}$ & $\mathbf{( 1 0 0 . 0 \% )}$ \\
\hline
\end{tabular}

We also examined whether there are differences across the grades for the item "Would you want to be in all boy/girl classroom next year? " by gender. Table 6. presents the results for this analysis. There appear to be differences across the grade levels between boys and girls. For example, only 68.4 percent of the first grade boys reported that they want to be in a single-gender class next year compared to 88.2 percent of the first-grade girls. However, none of these differences are statistically significant. Based on this analysis, the overall picture remains that students respond positively to single-gender classrooms (i.e., very few students reported that they would not want to be in a single-gender classroom next year).

Table 6. Would you Want to Be in All Boy/Girl Classroom Next Year? by Grade Level

\begin{tabular}{ccccc}
\hline & & Boys & Girls & Total \\
\hline \multirow{4}{*}{ Yes } & $1^{\text {st }}$ grade & $13(68.4 \%)$ & $15(88.2 \%)$ & $28(77.8 \%)$ \\
& $2^{\text {nd }}$ grade & $15(88.2 \%)$ & $14(87.5 \%)$ & $29(87.9 \%)$ \\
& $3^{\text {rd }}$ grade & $12(85.7 \%)$ & $10(76.9 \%)$ & $22(81.5 \%)$ \\
\multirow{4}{*}{ Maybe } & $4^{\text {th }}$ grade & $14(87.5 \%)$ & $13(68.4 \%)$ & $27(77.1 \%)$ \\
& $1^{\text {st }}$ grade & $2(10.5 \%)$ & $2(11.8 \%)$ & $4(11.1 \%)$ \\
& $2^{\text {nd }}$ grade & $1(5.9 \%)$ & $2(12.5 \%)$ & $3(9.1 \%)$ \\
& $3^{\text {rd }}$ grade & $1(7.1 \%)$ & $3(23.1 \%)$ & $4(14.8 \%)$ \\
No & $4^{\text {th }}$ grade & $1(6.3 \%)$ & $4(21.1 \%)$ & $5(14.3 \%)$ \\
& $1^{\text {st }}$ grade & $4(21.1 \%)$ & $0(0.0 \%)$ & $4(11.1 \%)$ \\
& $2^{\text {nd }}$ grade & $1(5.9 \%)$ & $0(0.0 \%)$ & $1(3.0 \%)$ \\
Total & $3^{\text {rd }}$ grade & $1(7.1 \%)$ & $0(0.0 \%)$ & $1(3.7 \%)$ \\
& $4^{\text {th }}$ grade & $1(6.3 \%)$ & $2(10.5 \%)$ & $3(8.6 \%)$ \\
& & $\mathbf{6 6}$ & $\mathbf{6 5}$ & $\mathbf{1 3 1}$ \\
& & $(\mathbf{1 0 0 . 0 \% )}$ & $\mathbf{( 1 0 0 . 0 \% )}$ & $\mathbf{( 1 0 0 . 0 \% )}$ \\
\hline
\end{tabular}

\section{Discussion}

Overall, the results from this survey suggest that students have positive attitudes toward their single-gender classrooms. Most students believe that the single-gender classroom format positively impacted them in many important school dimensions such as self-confidence, motivation, self-esteem, independence, self-efficacy, attitude, and grades. These results are similar to the results found in the State of South Carolina's studies of students in single-gender classrooms. The South Carolina report states that "more than $65 \%$ of thee students indicated their single-gender classes had increased their academic performance and attitudes." (South Carolina Department of Education, 2010).

While these results are very promising for single-gender education, we also found a few interesting differences between boys' and girls' responses to certain items. Specifically, girls responded more positively than boys on an item that might indicate that girls are more open to expressing their opinions in single-gender settings (i.e., girls reported that they ask questions and share ideas more when they are in their all-girl classes). This finding might support an important philosophical underpinning of single-gender education related to the breaking down of gender-specific 
stereotypes. When girls are in classes with boys, they might be less likely to ask questions and share their opinions.

Another important finding is that a large majority ( 81 percent) of students wanted to continue in the single-gender program the following year. We believe this positive outlook is due to how the single-gender teachers are prepared for these classrooms. Teachers at this school receive a substantial amount of professional development on single-gender pedagogy prior to and while working in single-gender classes. For example, the school organized book studies that focused on translating the research on gender differences into teaching strategies and pedagogical practices. Teachers also have opportunities to attend and present at professional conferences and to have continued dialogue with other single-gender teachers. We believe professional development training is imperative for successful programs. In other words, teachers must change their pedagogy to impact fully the learning of both genders. Ferrara (2010) asserts that meaningful professional development over a sustained time period is key developing effective teachers for single-gender classrooms. The recent law passed in Florida (HB 313) requires districts that chose to implement single-gender programs to provide training to teachers.

While the single-gender format might not be the best learning environment for every child, this study suggests that students in single-gender classrooms overwhelmingly like this organizational approach to schooling. Limitations of this research include that it only utilized a convenience sample of students from a single school and did not use a pre/post test design. Future research should incorporate students from multiple schools that utilize the single-gender classroom model as well as students who have multiple years of experience in both mixed-gender and single-gender classes. However, a particular challenge with larger scale research is variations in the ways the single-gender model is implemented in different schools.

\section{References}

Bigler, R., \& Signorella, M. (2011). Single-sex education: New perspectives and evidences on a continuing controversy. Sex Roles, 65(9-10), 659-669. http://dx.doi.org/10.1007/s11199-011-0046-x

Bracey, G.W. (2006). Separate but superior? A Review of Issues and Data Bearing on Single-Sex Education. Tempe, AZ: Arizona State University.

Ferrara, M. (2010). A chat with a passenger about single-gender learning. Advances in Gender and Education, 2, 34-38.

Office of Public School Choice and Innovation. (2010). Report on the Annual Survey of Single-Gender Programs in South Carolina Public Schools. Columbia, SC: South Carolina Department of Education.

Protheroe, N. (2009). Single-sex classrooms. Principals, 88(5), 32-35.

Salomone, R. (2013). Rights and wrongs in the debate over single-sex schooling. Boston Law Review, 93(3), 971-1027.

Spielhagen, F. (2006). How tweens view single-sex classes. Educational Leadership, 63(7), 71-72.

Spielhagen, F. (2013). Debating Single-Sex Education: Separate and Equal? Lanham, MD: Roman \& Littlefield Publishing.

Tichenor, M., Tichenor, J., Piechura, K., \& Heins, E. (2012). Hearing the voices of parents in single-gender classes. Advances in Gender and Education, 3, 7-13.

U.S. Department of Education. (2014). Single-Sex Versus Coeducational Schooling. CreateSpace Independent Publishing Platform. 